Check for updates

Cite this: Chem. Sci., 2019, 10, 2336

๑ All publication charges for this article have been paid for by the Royal Society of Chemistry

Received 27th November 2018 Accepted 20th December 2018

DOI: $10.1039 / \mathrm{c} 8 \mathrm{sc} 05275 a$

rsc.li/chemical-science

\section{Vacancy-enhanced generation of singlet oxygen for photodynamic therapy $\dagger$}

\author{
Shanyue Guan,,$^{\mathrm{a}}$ Li Wang, $^{\mathrm{ab}}$ Si-Min Xu,,$^{\mathrm{c}}$ Di Yang, ${ }^{\mathrm{b}}$ Geoffrey I. N. Waterhouse, ${ }^{d}$ \\ Xiaozhong Qu (D) *b and Shuyun Zhou*a
}

\begin{abstract}
Oxygen vacancy (OV) engineering in semiconductors can greatly enhance the separation of photo-induced electron-hole pairs, thereby enhancing the photocatalytic activity. Taking inspiration from this, we prepared a novel $\mathrm{BiOBr}-\mathrm{H} / \mathrm{Rub}_{2} \mathrm{~d}$ composite by functionalizing OV-rich $\mathrm{BiOBr}$ (named $\mathrm{BiOBr}-\mathrm{H}$ ) with a carboxyl functionalized ruthenium photosensitizer $\left(\mathrm{Ru}(\mathrm{bpy})_{2} \mathrm{C}-\mathrm{py} \mathrm{Cl}_{2}\right.$, abbreviated as $\mathrm{Rub} \mathrm{b}_{2} \mathrm{~d}$ ), which was then successfully applied for photodynamic therapy (PDT). Density functional theory (DFT) calculations confirmed efficient electron transfer from the Rub ${ }_{2} \mathrm{~d}$ complex to the intermediate energy level of $\mathrm{BiOBr}-$ $\mathrm{H}$ under visible light irradiation. In vitro and in vivo studies demonstrated that $\mathrm{BiOBr}-\mathrm{H} / \mathrm{Rub} \mathrm{b}_{2} \mathrm{~d}$ was a superior agent for photodynamic therapy compared with the free ruthenium complex. The theoretical and experimental data presented thus reveal for the first time that abundant $\mathrm{OVs}$ in $\mathrm{BiOBr}-\mathrm{H}$ can significantly improve the photocatalytic activity of a photosensitizer, resulting in the generation of more reactive oxygen species to enhance PDT. The findings of this study thus offer a new strategy for the development of highly efficient cancer therapies.
\end{abstract}

\section{Introduction}

Cancer has always been one of the most common diseases in humans, which has been a threat to human beings. ${ }^{1,2}$ Photodynamic therapy (PDT) has been widely applied in cancer treatment due to its non-invasive properties, few side effects, easy procedure and short treatment time relative to surgery or chemotherapy. ${ }^{3,4}$ In the PDT system, the mechanism is driven via the excitation of a photosensitizer (PS) to its triplet state, from which energy is then transferred to triplet oxygen, leading to the production of singlet oxygen $\left({ }^{1} \mathrm{O}_{2}\right) \cdot{ }^{5-7}$ Over the past decade, researchers have developed various PSs for PDT, including indocyanine green (ICG), ${ }^{8}$ chlorin e6 (Ce6), ${ }^{9-12}$ zinc phthalocyanine $(\mathrm{ZnPc}){ }^{13}$ and ruthenium ${ }^{13}$ complexes. ${ }^{\mathbf{1 4 , 1 5}}$ However, traditional PSs suffer from photo-bleaching under irradiation, resulting in the recombination of electron-hole pairs, leading to low production rates of singlet oxygen. ${ }^{\mathbf{1 6}}$

${ }^{a}$ Key Laboratory of Photochemical Conversion and Optoelectronic Materials, Technical Institute of Physics and Chemistry, Chinese Academy of Sciences, Beijing, 100190, P. R. China.E-mail:zhou_shuyun@mail.ipc.ac.cn

${ }^{b}$ College of Materials Science and Opto-Electronic Technology, University of Chinese Academy of Sciences, Beijing 100049, China.E-mail: quxz@iccas.ac.cn

${ }^{c}$ State Key Laboratory of Chemical Resource Engineering, Beijing University of Chemical Technology, 100029, Beijing, P. R. China

${ }^{d}$ School of Chemical Sciences, The University of Auckland, Auckland 1142, New Zealand

$\dagger$ Electronic supplementary information (ESI) available. See DOI: $10.1039 / \mathrm{c} 8 \mathrm{sc} 05275 \mathrm{a}$

\$ These authors equally contributed to this work.
Therefore, it is highly desirable to realize the reaction mechanism and discover a method that can prevent the recombination of electron-hole pairs and improve the PDT therapeutic effect.

As far as we are concerned, oxygen vacancies (OVs), i.e., the number of oxygen atoms expected in a compound is less (or missing) than what it should be in its perfect crystal lattice, ${ }^{\mathbf{1 7}}$ can facilitate photogenerated charge separation in semiconductors. $^{18,19}$ As a result, OVs can offer more carriers for surface reactions that lead to the generation of reactive oxygen species (ROS), such as ${ }^{1} \mathrm{O}_{2}, \mathrm{H}_{2} \mathrm{O}_{2}, \cdot \mathrm{O}_{2}{ }^{-}$, $\cdot \mathrm{OH}$, etc. ${ }^{20-22}$ OVs have always been considered as an effective electron trap since they are electron-deficient. ${ }^{2324}$ Recently, many semiconductors have been engineered with abundant OVs, including $\mathrm{TiO}_{2}, \mathrm{MnO}_{2}$ and BiOBr. ${ }^{25,26}$ By virtue of the abundant OVs, low toxicity, moderate band gap and outstanding photostability properties of $\mathrm{BiOBr},{ }^{17}$ we meticulously designed a novel composite by functionalizing OV-rich $\mathrm{BiOBr}$ (denoted as $\mathrm{BiOBr}-\mathrm{H}$ ) with a PS (ruthenium complexes). Under this circumstance, the generation of ROS (not only singlet oxygen but also superoxide and hydroxyl radicals) can be considerably enhanced, leading to outstanding PDT performance. This method can not only be applied in this specific system but also provide a mechanism for other PSs, resulting in a better understanding of the oxygen vacancy engineering PDT process.

Herein, a BiOBr-H/Rub ${ }_{2} \mathrm{~d}$ composite was successfully prepared via the interaction between $\mathrm{BiOBr}-\mathrm{H}$ and a ruthenium complex PS (di(2,2'-bipyridine) 2,2'-bipyridine-4,4'-dicarboxyl dichlororuthenium(II), denoted herein as $\operatorname{Rub}_{2} \mathrm{~d}$ ), as detailed in 
the ESI. $\uparrow$ Compared with the $\mathrm{Rub}_{2} \mathrm{~d}$ complex alone, the $\mathrm{BiOBr}-$ $\mathrm{H} / \mathrm{Rub}_{2} \mathrm{~d}$ agent can considerably improve the production of ROS under light irradiation, which can be verified by both ESR data and the DFT calculation. Specifically, the ${ }^{1} \mathrm{O}_{2}$ yield of $\mathrm{BiOBr}-\mathrm{H} /$ $\mathrm{Rub}_{2} \mathrm{~d}(0.49)$ was more than twice that of $\mathrm{Rub}_{2} \mathrm{~d}(0.22)$. Furthermore, both in vitro and in vivo studies confirmed that the $\mathrm{BiOBr}-\mathrm{H} / \mathrm{Rub}_{2} \mathrm{~d}$ composite was a potent PDT agent for cancer treatment. Density functional theory (DFT) calculations established that the photogenerated electrons of $\mathrm{Rub}_{2} \mathrm{~d}$ can be facilely transferred to the intermediate energy level located in the forbidden zone of $\mathrm{BiOBr}-\mathrm{H}$, facilitating electron-hole separation in $\mathrm{BiOBr}-\mathrm{H} / \mathrm{Rub}_{2} \mathrm{~d}$ and thus enhancing the ${ }^{1} \mathrm{O}_{2}$ yield. To demonstrate the general applicability of this strategy, here we additionally designed and synthesized two BiOBr-H/PS composites that bind specifically with the photosensitizers indocyanine green (ICG) and zinc phthalocyanine ( $\mathrm{ZnPc}$ ). As illustrated in our strategy, compared with the PS complex, the $\mathrm{BiOBr}-\mathrm{H} / \mathrm{PS}$ composite significantly increased the generation of ${ }^{1} \mathrm{O}_{2}$ under irradiation. Thus, this strategy of OV-enhanced generation of singlet oxygen holds great potential in the precise treatment of cancer.

\section{Results and discussion}

\section{Structural and morphological characterization}

BiOBr was fabricated via a hydrothermal method, ${ }^{27}$ followed by heating in $\mathrm{O}_{2}$ for $4 \mathrm{~h}$ (the product was denoted as $\mathrm{BiOBr}-\mathrm{H}$ ). The hydrothermally synthesized $\mathrm{BiOBr}$ without calcination was employed here for comparison purposes in PDT tests (and denoted simply as $\mathrm{BiOBr}$ ). The optimized geometries of the models BiOBr, BiOBr-H, Rub ${ }_{2} \mathrm{~d}, \mathrm{BiOBr} / \mathrm{Rub}_{2} \mathrm{~d}$, and $\mathrm{BiOBr}-\mathrm{H} /$ $\mathrm{Rub}_{2} \mathrm{~d}$ are displayed in Scheme 1. Ru(bpy) ${ }_{2} \mathrm{C}-\mathrm{pyCl}_{2}$ (denoted as $\mathrm{Rub}_{2} \mathrm{~d}$ ) was prepared via a two-step reaction of ruthenium chloride with 2,2'-bipyridine and 2,2'-bipyridine-4,4'-dicarboxylic acid, the molecular structure of which is shown in Fig. S1. $\dagger$ $\mathrm{BiOBr}-\mathrm{H} / \mathrm{Rub}_{2} \mathrm{~d}$ and $\mathrm{BiOBr} / \mathrm{Rub}_{2} \mathrm{~d}$ were synthesized via the electrostatic attraction between positively charged $\mathrm{BiOBr}-\mathrm{H}$ (zeta potential $+12.60 \mathrm{mV}$ ) and negatively charged $\mathrm{Ru}(\mathrm{bpy})_{2} \mathrm{C}$ $\mathrm{pyCl}_{2}$ (zeta potential $-0.97 \mathrm{mV}$ ). The zeta potential of the resulting composite product is measured to be $+12.30 \mathrm{mV}$ (Fig. S2†).

Powder X-ray diffraction (XRD) was used to characterize the structures of the various samples (Fig. 1a). $\mathrm{BiOBr}, \mathrm{BiOBr}-\mathrm{H}$, $\mathrm{BiOBr} / \mathrm{Rub}_{2} \mathrm{~d}$ and $\mathrm{BiOBr}-\mathrm{H} / \mathrm{Rub}_{2} \mathrm{~d}$ all showed diffraction patterns typical of BiOBr (JCPDS, PDF \#73-2061). Transmission electron microscopy (TEM) and elemental mapping (EM) were used to examine the compositional uniformity of $\mathrm{BiOBr}-\mathrm{H} /$ $\mathrm{Rub}_{2} \mathrm{~d}$. TEM (Fig. $1 \mathrm{~b}$ and $\mathrm{c}$ ) revealed that $\mathrm{BiOBr}-\mathrm{H} / \mathrm{Rub}_{2} \mathrm{~d}$ possessed a plate-like shape with a diameter of around $200 \mathrm{~nm}$. The lattice fringe spacing of $0.346 \mathrm{~nm}$ can be attributed to the (011) plane of BiOBr-H (Fig. 1b). Furthermore, TEM images of $\mathrm{BiOBr}-\mathrm{H}$ were recorded after incubation in the cell culture medium (DMEM) or buffer solution (PBS) pH 6.5 with $\mathrm{H}_{2} \mathrm{O}_{2}$ (tumor microenvironment) for $24 \mathrm{~h}$. As shown in Fig. S3† the morphology of BiOBr-H showed no apparent change after $24 \mathrm{~h}$ of incubation, indicating that $\mathrm{BiOBr}-\mathrm{H}$ was stable in the acidic environment and cell culture medium. Atomic force microscopy

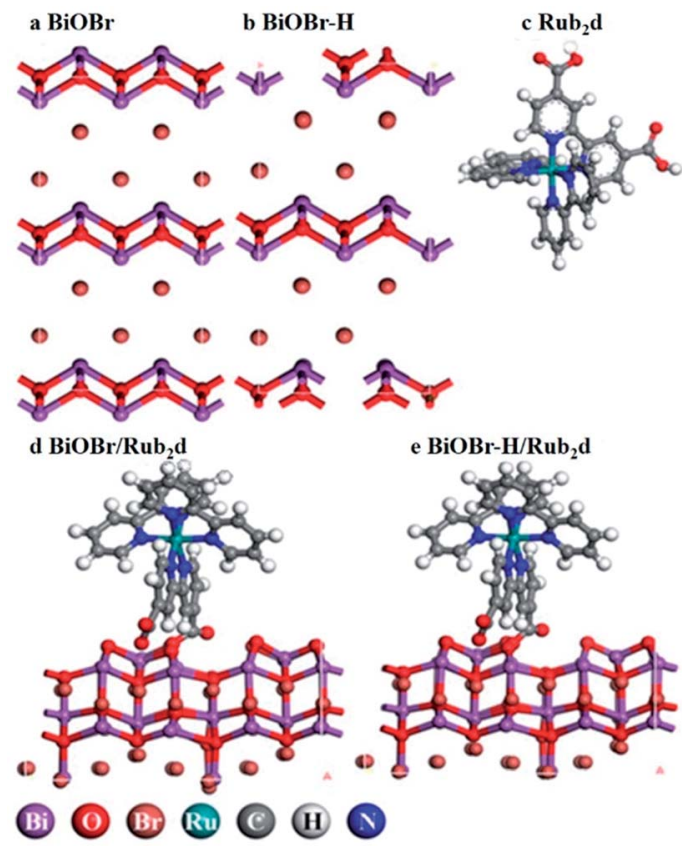

Scheme 1 Schematic illustration of the optimized geometries of $\mathrm{BiOBr}, \mathrm{BiOBr}-\mathrm{H}, \mathrm{Rub}_{2} \mathrm{~d}, \mathrm{BiOBr} / \mathrm{Rub}_{2} \mathrm{~d}$, and $\mathrm{BiOBr}-\mathrm{H} / \mathrm{Rub}{ }_{2} \mathrm{~d}$. The detailed chemical structure of Rub ${ }_{2} \mathrm{~d}$ is listed in Fig. S1. $\dagger$

(AFM) determined the thickness of the sheets in $\mathrm{BiOBr}-\mathrm{H} /$ $\mathrm{Rub}_{2} \mathrm{~d}$ to be approximately $1.0 \mathrm{~nm}$ (Fig. S4†). Elemental mapping images demonstrate that the $\mathrm{Rub}_{2} \mathrm{~d}$ complex was uniformly distributed over the BiOBr-H surface (Fig. 1d).

UV-vis absorption spectra of $\mathrm{BiOBr}-\mathrm{H}, \mathrm{BiOBr}, \mathrm{Rub}_{2} \mathrm{~d}, \mathrm{BiOBr} /$ $\mathrm{Rub}_{2} \mathrm{~d}$ and $\mathrm{BiOBr}-\mathrm{H} / \mathrm{Rub}_{2} \mathrm{~d}$ are presented in Fig. S5. $\dagger$ BiOBr and BiOBr-H displayed weak absorption across the $300-900 \mathrm{~nm}$
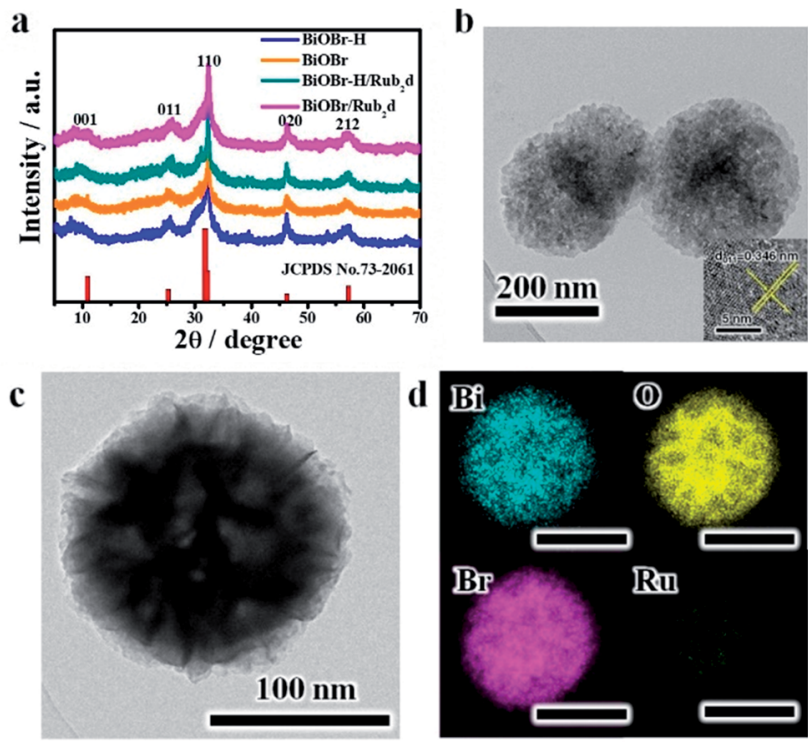

Fig. 1 (a) XRD patterns for $\mathrm{BiOBr}, \mathrm{BiOBr} / \mathrm{Rub}_{2} \mathrm{~d}, \mathrm{BiOBr}-\mathrm{H}$ and $\mathrm{BiOBr}-$ $\mathrm{H} / \mathrm{Rub}_{2} \mathrm{~d}$; the standard PDF card for $\mathrm{BiOBr}$ is also shown (JCPDS no. 73-2061). (b) TEM image (inset: HRTEM image) and ( $c$ and d) elemental maps for $\mathrm{BiOBr}-\mathrm{H} / \mathrm{Rub}_{2} \mathrm{~d}$. 
region. After functionalization with the $\mathrm{Rub}_{2} \mathrm{~d}$ complex, a strong absorption signal at $460 \mathrm{~nm}$ appeared, which can readily be attributed to metal-to-ligand charge-transfer (MLCT) transitions in the $\mathrm{Rub}_{2} \mathrm{~d}$ complex. ${ }^{28}$ Fourier transform infrared (FT-IR) spectroscopy was utilized to analyze the functional groups present in the various samples. For pristine $\mathrm{BiOBr}$ and $\mathrm{BiOBr}-\mathrm{H}$ (Fig. S6†), peaks at $527 \mathrm{~cm}^{-1}$ and $3445 \mathrm{~cm}^{-1}$ were observed and assigned to the $\mathrm{Bi}-\mathrm{O}$ stretching and $\mathrm{O}-\mathrm{H}$ stretching modes, respectively. The peak at $2870 \mathrm{~cm}^{-1}$ is a $\mathrm{C}-\mathrm{H}$ stretching vibration of polyvinyl pyrrolidone (PVP). ${ }^{29}$ This feature was much weaker for BiOBr-H. The Rub $\mathrm{d}_{2} \mathrm{~d}$ complex showed a strong peak around $1700 \mathrm{~cm}^{-1}$ due to the carboxylate groups of the C-py ligand $^{30}$ (Fig. S6 $\dagger$ ). The spectra of $\mathrm{BiOBr} / \mathrm{Rub}_{2} \mathrm{~d}$ and $\mathrm{BiOBr}-\mathrm{H} /$ $\mathrm{Rub}_{2} \mathrm{~d}$ also show the IR peaks of the Rub $\mathrm{d}_{2} \mathrm{~d}$ complex, confirming the successful loading of the $\mathrm{Rub}_{2} \mathrm{~d}$ complex onto these materials.

The chemical composition of BiOBr, BiOBr-H, Rub ${ }_{2} \mathrm{~d}$, and $\mathrm{BiOBr}-\mathrm{H} / \mathrm{Rub}_{2} \mathrm{~d}$ was further probed by X-ray photoelectron spectroscopy (XPS) (Fig. S7-S10 and Table S1†). Comparing the spectra of $\mathrm{BiOBr}$ and $\mathrm{BiOBr}-\mathrm{H}$, the most obvious difference is the absence of the $\mathrm{C} 1 \mathrm{~s}$ and $\mathrm{N} 1 \mathrm{~s}$ signals in the survey spectrum of $\mathrm{BiOBr}-\mathrm{H}$. This is explained by the decomposition of PVP during the calcination step used to synthesize $\mathrm{BiOBr}-\mathrm{H}$. The spectrum of the Rub $\mathrm{d}_{2}$ complex displayed signals due to $\mathrm{Ru}, \mathrm{O}$, $\mathrm{N}$ and $\mathrm{C}$, whilst that of the $\mathrm{BiOBr}-\mathrm{H} / \mathrm{Rub}_{2} \mathrm{~d}$ complex contained signals due to $\mathrm{C}, \mathrm{O}, \mathrm{Br}, \mathrm{Ru}, \mathrm{N}$ and $\mathrm{Bi}$ elements (Fig. S7-S8†). High-resolution $\mathrm{Bi}$ 4f XPS spectra of $\mathrm{BiOBr}$ and $\mathrm{BiOBr}-\mathrm{H}$ (Fig. S9†) showed two peaks at 158.9 and $164.2 \mathrm{eV}$ in a $4: 3$ area ratio, which can readily be assigned to the $\mathrm{Bi} 4 \mathrm{f}_{7 / 2}$ and $4 \mathrm{f}_{5 / 2}$ peaks of $\mathrm{Bi}^{3+} \cdot{ }^{26}$ For $\mathrm{BiOBr}-\mathrm{H}$, two additional peaks are seen at 157.8 and $163.5 \mathrm{eV}$ which are assigned to the $\mathrm{Bi} 4 \mathrm{f}_{7 / 2}$ and $4 \mathrm{f}_{5 / 2}$ peaks of $\mathrm{Bi}^{3+}$ near oxygen vacancies. ${ }^{26}$ The $\mathrm{O} 1 \mathrm{~s}$ spectrum (Fig. S10†) of BiOBr-H was deconvoluted into two peaks at 529.7 and $530.9 \mathrm{eV}$. The intense peak at $529.7 \mathrm{eV}$ is typical of lattice oxygen $\left(\mathrm{O}^{2-}\right)$ in $\mathrm{BiOBr}-\mathrm{H}$, whereas the weaker peak at higher binding energy is due to the adsorbed hydroxyl species or oxygen species at vacancy sites $\left(\mathrm{O}^{-}\right) \cdot{ }^{19}$ The combination of the $\mathrm{Bi}$ $4 \mathrm{f}$ and $\mathrm{O} 1 \mathrm{~s}$ data provides good evidence for the presence of OVs in the BiOBr-H sample.

Due to the intrinsic fluorescence properties of the $\mathrm{Rub}_{2} \mathrm{~d}$ complex, we probed the fluorescence properties of $\mathrm{Rub}_{2} \mathrm{~d}$, $\mathrm{BiOBr}-\mathrm{H} / \mathrm{Rub}_{2} \mathrm{~d}$ and $\mathrm{BiOBr} / \mathrm{Rub}_{2} \mathrm{~d}$. All samples displayed an obvious fluorescence signal centered at $650 \mathrm{~nm}$ (similar to $\mathrm{Rub}_{2} \mathrm{~d}$ at a concentration of $250 \mu \mathrm{g} \mathrm{mL}^{-1}$ ) (Fig. S11 $\dagger$ ). To further characterize the fluorescence performance of the samples, the two-photon fluorescence intensities of $\mathrm{BiOBr}, \mathrm{BiOBr}-\mathrm{H}, \mathrm{Rub}_{2} \mathrm{~d}$, $\mathrm{BiOBr} / \mathrm{Rub}_{2} \mathrm{~d}$ and $\mathrm{BiOBr}-\mathrm{H} / \mathrm{Rub}_{2} \mathrm{~d}$ were examined under $800 \mathrm{~nm}$ irradiation (Fig. S12 $\dagger$ ). Rub $\mathrm{d}_{2} \mathrm{~d}$ exhibited a higher up-conversion photoluminescence (UCPL) intensity than $\mathrm{BiOBr}-\mathrm{H} / \mathrm{Rub}_{2} \mathrm{~d}$, whilst no two-photon signal was seen for $\mathrm{BiOBr}$ and $\mathrm{BiOBr}-\mathrm{H}$. For $\mathrm{BiOBr}-\mathrm{H} / \mathrm{Rub}_{2} \mathrm{~d}$, a quadratic relationship was found between the laser power and the fluorescence intensity, confirming that the up-conversion photoluminescence emission of the sample was due to a two-photon excitation process (Fig. S13 $\dagger$ ). The emission lifetime of $\mathrm{Rub}_{2} \mathrm{~d}$ and $\mathrm{BiOBr}-\mathrm{H} / \mathrm{Rub}_{2} \mathrm{~d}$ was further examined under $520 \mathrm{~nm}$ excitation. The emission lifetime of BiOBr-H/Rub ${ }_{2} \mathrm{~d}$ was $309.44 \mathrm{~ns}$, longer than that of pristine $\mathrm{Rub}_{2} \mathrm{~d}$ in solution (234.47 ns) (Fig. S14 and Table S2 $\dagger$ ). This proves conclusively that the triple state of $\mathrm{Rub}_{2} \mathrm{~d}$ was enhanced by interaction with $\mathrm{BiOBr}-\mathrm{H} .^{31,32}$

Electron Spin Resonance (ESR) was applied to quantify vacancy-induced ${ }^{1} \mathrm{O}_{2}$ generation. As shown in Fig. 2a, the pristine $\mathrm{BiOBr}$ possessed few vacancies. However, the ESR spectrum of $\mathrm{BiOBr}-\mathrm{H}$ revealed a greatly enhanced OV signal, resulting from the calcination step used in its synthesis. In comparison, $\mathrm{BiOBr}-$ $\mathrm{H} / \mathrm{Rub}_{2} \mathrm{~d}$ contained relatively few vacancies (as did $\mathrm{BiOBr} / \mathrm{Rub}_{2} \mathrm{~d}$ ). Using 2,2,6,6-tetramethylpiperidine (Temp) as an ${ }^{1} \mathrm{O}_{2}$ trap (Fig. 2b), BiOBr, BiOBr-H, BiOBr/Rub $/ \mathrm{R}_{2} \mathrm{~d}, \mathrm{BiOBr}-\mathrm{H} / \mathrm{Rub}_{2} \mathrm{~d}$, and $\mathrm{Rub}_{2} \mathrm{~d}$ all gave similar signals prior to irradiation. Following irradiation, the ${ }^{1} \mathrm{O}_{2}$ signal of $\mathrm{BiOBr}-\mathrm{H} / \mathrm{Rub}_{2} \mathrm{~d}$ increased significantly, whereas the signals of $\mathrm{BiOBr} / \mathrm{Rub}_{2} \mathrm{~d}$ and $\mathrm{Rub}_{2} \mathrm{~d}$ did not change much. The ${ }^{1} \mathrm{O}_{2}$ signal of irradiated $\mathrm{BiOBr}-\mathrm{H} / \mathrm{Rub}_{2} \mathrm{~d}$ was twice that of $\mathrm{Rub}_{2} \mathrm{~d}$ (Fig. 2c). Clearly, the abundant OVs in BiOBr$\mathrm{H} / \mathrm{Rub}_{2} \mathrm{~d}$ are effective for the capture of electrons, ${ }^{23,33}$ thereby suppressing electron-hole pair recombination in the semiconductor. Accordingly, the excited electrons transferred from $\mathrm{Rub}_{2} \mathrm{~d}$ under xenon lamp irradiation are captured by the OVs in $\mathrm{BiOBr}-\mathrm{H}$, leading to enhanced generation of ${ }^{1} \mathrm{O}_{2}$.

To determine the optimal $\mathrm{Rub}_{2} \mathrm{~d}$ loading capacity, a series of $\mathrm{BiOBr}-\mathrm{H} / \mathrm{Rub}_{2} \mathrm{~d}(x \%)$ were prepared and their ESR spectra were collected under xenon lamp irradiation (Fig. 2d). The ESR signal increased from $\mathrm{BiOBr}-\mathrm{H} / \mathrm{Rub}_{2} \mathrm{~d}(25 \%)$ to $\mathrm{BiOBr}-\mathrm{H} / \mathrm{Rub}_{2} \mathrm{~d}$ (200\%). The signal intensity gradually decreased as the loading was increased from BiOBr-H/Rub $\mathrm{d}_{2}(200 \%)$ to $\mathrm{BiOBr}-\mathrm{H} / \mathrm{Rub}_{2} \mathrm{~d}$ (400\%) (Fig. 2d and S15†). Therefore, BiOBr/Rub ${ }_{2} \mathrm{~d}(200 \%)$ displayed the optimum performance and we used this $\mathrm{Rub}_{2} \mathrm{~d}$ loading in all subsequent experiments. In addition, to further realize this oxygen-vacancy engineering mechanism, we further prove the generation of other radical species, e.g., $\cdot \mathrm{O}_{2}{ }^{-}$and $\cdot \mathrm{OH}$ of ROS. As expected, the ESR signal of $\cdot \mathrm{O}_{2}{ }^{-}$and $\cdot \mathrm{OH}$ was also
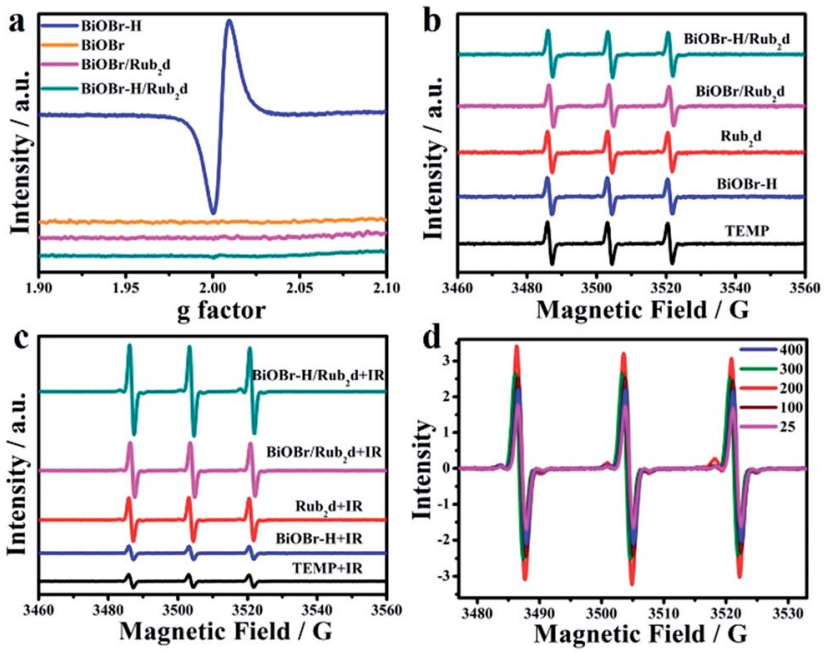

Fig. 2 (a) ESR spectra of $\mathrm{BiOBr}-\mathrm{H}, \mathrm{BiOBr}, \mathrm{Rub}_{2} \mathrm{~d}$ and $\mathrm{BiOBr}-\mathrm{H} / \mathrm{Rub} \mathrm{b}_{2} \mathrm{~d}$ (500 $\mu \mathrm{g} \mathrm{mL}^{-1}$ ) without irradiation and (b) ESR spectra of $\mathrm{BiOBr}-\mathrm{H}$, $\mathrm{BiOBr}, \mathrm{BiOBr} / \mathrm{Rub}_{2} \mathrm{~d}$ and $\mathrm{BiOBr}-\mathrm{H} / \mathrm{Rub}_{2} \mathrm{~d}\left(500 \mu \mathrm{g} \mathrm{m}^{-1}\right)$ without irradiation and (c) with irradiation using a xenon lamp $\left(100 \mathrm{~mW} \mathrm{~cm}^{-2}\right)$ for 10 min. (d) ESR spectra of $\mathrm{BiOBr}-\mathrm{H} / \mathrm{Rub}_{2} \mathrm{~d}$ with different loadings after irradiation for $10 \mathrm{~min}\left(\mathrm{Rub}_{2} \mathrm{~d}\right.$ concentration $500 \mu \mathrm{g} \mathrm{mL}^{-1}$ ). 
significantly enhanced as the irradiation time increased from $0 \mathrm{~min}$ to $10 \mathrm{~min}$ (Fig. S16 $\dagger$ ). This can further support our oxygen-vacancy engineering generation of ROS, which can be applied as a tool for the improvement of cancer therapy.

DFT calculations were used to gain deeper insights about the impact of oxygen-vacancy engineering on the generation of singlet oxygen. The schematic illustration of the structures of $\mathrm{BiOBr}$ and BiOBr$-\mathrm{H}$ is displayed in Fig. S17. $\dagger$ The surface energies of the low-index facets of $\mathrm{BiOBr}$ were first calculated and are listed in Table S3. $\uparrow$ It was found that the (011) facet of BiOBr possesses the smallest surface energy $\left(0.428 \mathrm{~J} \mathrm{~m}^{-2}\right)$, revealing that the (011) facet will be preferentially exposed on the surface of $\mathrm{BiOBr}$ and $\mathrm{BiOBr}-\mathrm{H}$, in good agreement with the HRTEM findings (Fig. 1b). The density of states of both $\mathrm{BiOBr}$ and $\mathrm{BiOBr}-$ $\mathrm{H}$ is subsequently calculated and displayed in Fig. $3 \mathrm{a}$ and $\mathrm{b}$. The band gap energy of BiOBr was calculated to be $2.70 \mathrm{eV}$, in good accord with that estimated from the UV-vis absorbance spectrum (Fig. S4 $\dagger$ ). For BiOBr-H, an intermediate energy level appears in the forbidden zone, resulting from the presence of abundant oxygen vacancies..$^{34,35}$ The density of states of $\mathrm{BiOBr}-\mathrm{H}$ indicates that the intermediate energy level is mainly composed of Bi-6p orbitals (Fig. S18 ). Using the work functions determined for $\mathrm{BiOBr}$ and $\mathrm{BiOBr}-\mathrm{H}$, the positions of their conduction band minimum (CBM) and valence band maximum (VBM) were calculated (Fig. 3c). The HOMO and LUMO positions of the Rub $_{2} \mathrm{~d}$ complex were also calculated and are displayed in Fig. 3c. The calculations reveal that the photogenerated electrons in $\mathrm{Rub}_{2} \mathrm{~d}$ can be efficiently transferred to the intermediate energy level of $\mathrm{BiOBr}-\mathrm{H}$ with a large driving force of $1.311 \mathrm{eV}$, thereby facilitating rapid electron-hole separation. Similar defectinduced charge separation has also been reported in previous work. ${ }^{36,37}$ Furthermore, the binding energy between BiOBr-H and $\mathrm{Rub}_{2} \mathrm{~d}$ was determined to be $-4.482 \mathrm{eV}$, confirming the strong interaction between BiOBr-H and $\mathrm{Rub}_{2} \mathrm{~d}$.

\section{Measurements of singlet oxygen}

We further investigated ${ }^{1} \mathrm{O}_{2}$ generation via a chemical trapping experiment using 1,3-diphenylisobenzofuran (DPBF) as

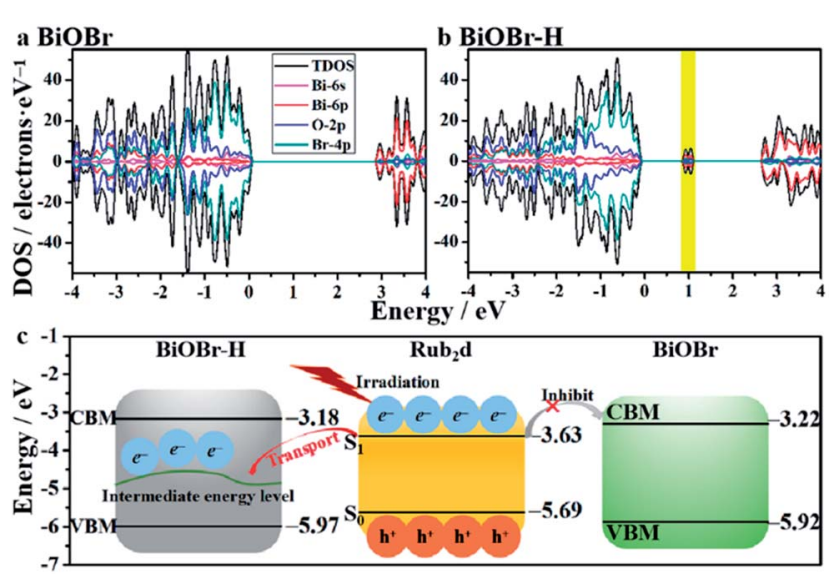

Fig. 3 Band structures of $\mathrm{BiOBr}(\mathrm{a})$ and $\mathrm{BiOBr}-\mathrm{H}$ (b). The band edge positions of $\mathrm{BiOBr}, \mathrm{BiOBr}-\mathrm{H}$ and $\mathrm{Rub}_{2} \mathrm{~d}$ with the vacuum level set at $0 \mathrm{eV}$ (c). a trapping agent and Rose Bengal (RB) as a standard photosensitizer $\left({ }^{1} \mathrm{O}_{2}\right.$ quantum yield $\Phi_{\mathrm{RB}}=0.86$ in ethanol). The absorption of DPBF at $410 \mathrm{~nm}$ was monitored under $520 \mathrm{~nm}$ irradiation, to follow the decay rate of the photosensitizing process. The detailed calculations used in this analysis are provided in Fig. S19. $\dagger$ The absorbance of the DPBF solution at $410 \mathrm{~nm}$ decreased quite quickly with irradiation time in the presence of $\mathrm{BiOBr}-\mathrm{H} / \mathrm{Rub}_{2} \mathrm{~d}$, confirming the fast generation of ${ }^{1} \mathrm{O}_{2}$. In comparison, the decrease in the absorbance at $410 \mathrm{~nm}$ was relatively slow in the presence of $\mathrm{BiOBr} / \mathrm{Rub}_{2} \mathrm{~d}$ and $\mathrm{Rub}_{2} \mathrm{~d}$, again confirming that the OVs in $\mathrm{BiOBr}-\mathrm{H} / \mathrm{Rub}_{2} \mathrm{~d}$ facilitate ${ }^{1} \mathrm{O}_{2}$ generation. The ${ }^{1} \mathrm{O}_{2}$ quantum yield of $\mathrm{BiOBr}-\mathrm{H} / \mathrm{Rub}_{2} \mathrm{~d}$ was calculated to be 0.49 , which is approximately 2 -fold higher than that of $\mathrm{Rub}_{2} \mathrm{~d}$ alone $(0.22)$. To further evaluate the benefits of the oxygen vacancies in $\mathrm{BiOBr}-\mathrm{H}$ for promoting ${ }^{1} \mathrm{O}_{2}$ generation, we loaded the photosensitizers zinc phthalocyanine $(\mathrm{ZnPc}$ ) and indocyanine green (ICG) on $\mathrm{BiOBr}-\mathrm{H}$ and studied the generation of ${ }^{1} \mathrm{O}_{2}$ via $\mathrm{UV}$-vis spectroscopy. The singlet oxygen yields of $\mathrm{BiOBr}-\mathrm{H} / \mathrm{ZnPc}$ and $\mathrm{BiOBr}-\mathrm{H} / \mathrm{ICG}$ were 0.50 and 0.28 , respectively (Table $\mathrm{S} 4 \dagger$ ), much higher than those of ZnPc (0.31) and ICG (0.15) (Fig. S20 and S21†). Photocurrent response measurements provided further evidence for the excellent charge transfer properties of $\mathrm{BiOBr}-$ $\mathrm{H} / \mathrm{Rub}_{2} \mathrm{~d}$. As expected, $\mathrm{Rub}_{2} \mathrm{~d}$ and $\mathrm{BiOBr}-\mathrm{H}$ showed only a weak photocurrent response, whereas $\mathrm{BiOBr}-\mathrm{H} / \mathrm{Rub}_{2} \mathrm{~d}$ showed a remarkable photocurrent response (Fig. S22†). Therefore, it can be concluded that the incorporation of the probe $\mathrm{Rub}_{2} \mathrm{~d}$ into $\mathrm{BiOBr}-\mathrm{H}$ can accelerate the generation of ${ }^{1} \mathrm{O}_{2}$ from the $\mathrm{Rub}_{2} \mathrm{~d}$. To summarize, adsorption of $\mathrm{Rub}_{2} \mathrm{~d}$ on OV-rich BiOBr-H enhances the population of the Rub $_{2} \mathrm{~d}$ triplet state (evidenced by a phosphorescence lifetime increase). Facile electron transfer occurs from excited $\mathrm{Rub}_{2} \mathrm{~d}$ to $\mathrm{BiOBr}-\mathrm{H}$.

\section{In vitro anticancer activity}

The internalization and in vitro cellular bio-imaging of the $\mathrm{BiOBr}-\mathrm{H} / \mathrm{Rub}_{2} \mathrm{~d}$ was assessed on the Hela cell line using a Laser Scanning Confocal Microscope (LSCM) with an excitation wavelength of $488 \mathrm{~nm}$. After incubation with $\mathrm{BiOBr}-\mathrm{H} / \mathrm{Rub}_{2} \mathrm{~d}$ for $24 \mathrm{~h}$, the nucleus of the cells was stained with DAPI which gives a blue color emission. Fig. S23† shows that the BiOBr-H/ $\mathrm{Rub}_{2} \mathrm{~d}$ was internalized by cells through endocytosis ${ }^{38}$ and was mainly located in the cytoplasm. Furthermore, from the TEM observation (Fig. S24†), the BiOBr-H/Rub ${ }_{2}$ d samples can be internalized by the Hela cells and then enter mitochondria while the others accumulate in lysosomes. ${ }^{38}$ In addition, elemental mapping can vividly monitor the $\mathrm{Bi}, \mathrm{Br}$ and $\mathrm{Ru}$ distribution during the cell culture and the results confirmed the stability of BiOBr-H/Rub $2 \mathrm{~d}$ inside Hela cells (Fig. S25†). We further investigated the two-photon imaging properties of $\mathrm{BiOBr}-\mathrm{H} / \mathrm{Rub}_{2} \mathrm{~d}$ using three various cell lines: Hela, HepG-2 and MCF-7 cells. As shown in Fig. S26, $\uparrow$ the cells exhibit fluorescence in the green and red channels under $800 \mathrm{~nm}$ excitation. This confirms the potential of $\mathrm{BiOBr}-\mathrm{H} / \mathrm{Rub}_{2} \mathrm{~d}$ as an imaging agent for the detection of cancer cells via two-photon fluorescence imaging techniques. 
To confirm the anticancer activity of $\mathrm{BiOBr}-\mathrm{H} / \mathrm{Rub}_{2} \mathrm{~d}$ was solely due to the photodynamic therapy, the cytotoxicity of $\mathrm{BiOBr}$ and $\mathrm{BiOBr}-\mathrm{H}$ was checked by the CCK8 assay in Hela cells (Fig. S27 $\dagger$ ). After $24 \mathrm{~h}$ of incubation, BiOBr and $\mathrm{BiOBr}-\mathrm{H}$ showed negligible toxicity towards the Hela cells even at concentrations up to $500 \mu \mathrm{g} \mathrm{mL}{ }^{-1}$. Further, Rub $\mathrm{m}_{2} \mathrm{~d}, \mathrm{BiOBr} /$ $\mathrm{Rub}_{2} \mathrm{~d}$, and $\mathrm{BiOBr}-\mathrm{H} / \mathrm{Rub}_{2} \mathrm{~d}$ also showed negligible toxicity (Fig. 4a). Rub ${ }_{2}$ d and BiOBr/Rub ${ }_{2}$ d slightly inhibited the growth of the Hela cells, following irradiation for 10 min (Fig. 4a). Remarkably, the growth of Hela cells was significantly inhibited when incubated with $\mathrm{BiOBr}-\mathrm{H} / \mathrm{Rub}_{2} \mathrm{~d}$ and irradiated at $520 \mathrm{~nm}$ $\left(100 \mathrm{~mW} \mathrm{~cm}^{-2}\right)$ for $10 \mathrm{~min}$. Similar results were obtained for the MCF-7 and HepG-2 cell lines (Fig. S28 and S29†). To visualize the PDT effect on the cells, the dead and live cells were stained with Propidium Iodide (PI) and calcein-AM, respectively (Fig. 4b). It is apparent that the majority of cells were dead after being treated with the $\mathrm{BiOBr}-\mathrm{H} / \mathrm{Rub}_{2} \mathrm{~d}$ and irradiated, whereas they remained in relatively good condition without irradiation. The effect of illumination on $\mathrm{Rub}_{2} \mathrm{~d}$ treated cells is less obvious. Again, the data point to a synergistic effect resulting from the adsorption of $\mathrm{Rub}_{2} \mathrm{~d}$ on $\mathrm{BiOBr}-\mathrm{H}$. To validate the benefits of $\mathrm{OV}$ engineering for ROS generation in vitro, $2^{\prime}, 7^{\prime}$-dichlorofluorescin diacetate (DCFH-DA) was used. Following diffusion into cells, DCFH-DA is deacetylated by cellular esterases to give a nonfluorescent compound, which can be oxidized by ROS into $2^{\prime}, 7^{\prime}$ dichlorofluorescein (DCF), which has characteristic excitation and emission maxima of 488 and $525 \mathrm{~nm}$, respectively. ${ }^{39}$ Hela
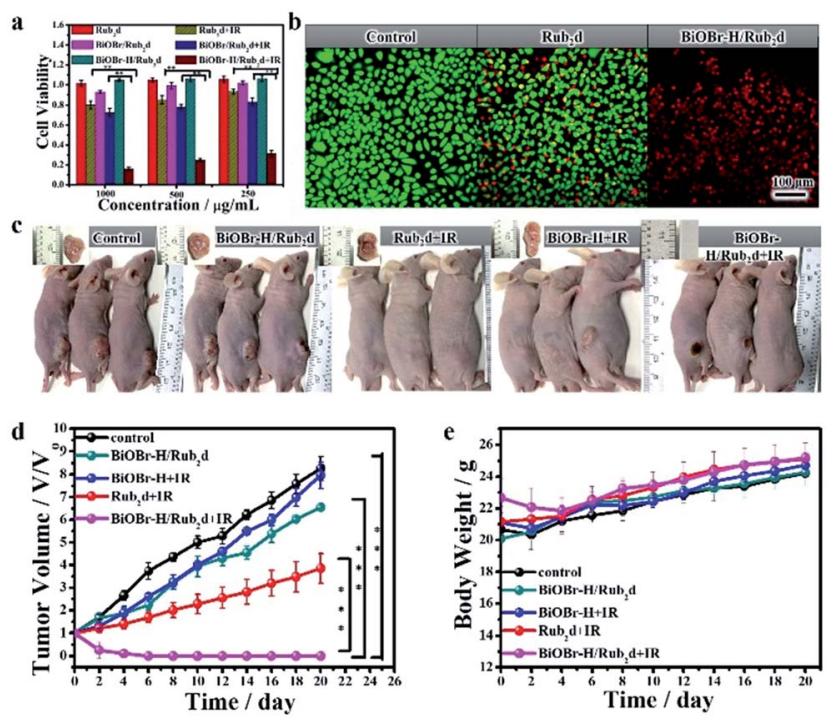

Fig. 4 (a) Cell viability of Hela cells incubated with $\mathrm{Rub}_{2} \mathrm{~d}, \mathrm{BiOBr}-\mathrm{H}$ / $\mathrm{Rub}_{2} \mathrm{~d}$ or $\mathrm{BiOBr} / \mathrm{Rub}_{2} \mathrm{~d}$ for $24 \mathrm{~h}$ with and without irradiation (xenon lamp, $100 \mathrm{~mW} \mathrm{~cm}^{-2}$ ), respectively. The viability was the average of six measurements $(n=6)$. (b) Fluorescence imaging of $\mathrm{Rub}_{2} \mathrm{~d}$ and $\mathrm{BiOBr}-$ $\mathrm{H} /$ Rub $_{2} \mathrm{~d}$ with and without IR therapy, respectively. Live/dead Hela cells are green/red (calcein AM/PI), respectively. (c) In vivo photographs of various groups of mice administrated with $200 \mu \mathrm{L}$ of PBS, $\mathrm{BiOBr}-\mathrm{H}, \mathrm{Rub}_{2} \mathrm{~d}$ or $\mathrm{BiOBr}-\mathrm{H} / \mathrm{Rub}_{2} \mathrm{~d}$ with or without $520 \mathrm{~nm}$ irradiation for $10 \mathrm{~min}$ (xenon lamp, $100 \mathrm{~mW} \mathrm{~cm}^{-2}$ ). (d) Tumor size and (e) body weight. The tumor volume was the average of five measurements $(n=$ $5)$ and the error bars indicate the standard deviation. $* p<0.05, * * p<$ 0.01 , and $* * * p<0.001$. cells treated with phosphate-buffered saline (PBS) and irradiated at $520 \mathrm{~nm}$ with a luminous power of $100 \mathrm{~mW} \mathrm{~cm}^{-2}$ for 10 min showed a typical Hela cell green fluorescence signal (Fig. S30 †). Cells incubated with $\mathrm{BiOBr}-\mathrm{H} / \mathrm{Rub}_{2} \mathrm{~d}$ and $\mathrm{Rub}_{2} \mathrm{~d}$ showed a significantly enhanced green fluorescence due to the generation of DCF. The intensity of the fluorescence signal was strongly dependent on the incubation time. However, at all incubation times $\mathrm{BiOBr}-\mathrm{H} / \mathrm{Rub}_{2} \mathrm{~d}$ demonstrated the strongest green fluorescence signal.

\section{Fluorescence imaging and in vivo antitumor assay}

Encouraged by the in vitro PDT efficacy of $\mathrm{BiOBr}-\mathrm{H} / \mathrm{Rub}_{2} \mathrm{~d}$, in vivo PDT experiments were subsequently performed involving monitoring of the volume of the tumors after irradiation. Hela tumor-bearing mice were divided into 5 groups (control group, $\mathrm{BiOBr}-\mathrm{H} / \mathrm{Rub}_{2} \mathrm{~d}, \mathrm{BiOBr}+\mathrm{IR}, \mathrm{Rub}_{2} \mathrm{~d}+\mathrm{IR}$, and BiOBr$-\mathrm{H} / \mathrm{Rub}_{2} \mathrm{~d}+$ IR), with each group having 5 mice (Fig. 4c). No significant therapeutic effect was seen for the $\mathrm{BiOBr}-\mathrm{H} / \mathrm{Rub}_{2} \mathrm{~d}$ group without irradiation and $\mathrm{BiOBr}$ with irradiation. In contrast, the tumor volumes for the $\mathrm{Rub}_{2} \mathrm{~d}+\mathrm{IR}$ group decreased. Notably, the tumor volume of the $\mathrm{BiOBr}-\mathrm{H} / \mathrm{Rub}_{2} \mathrm{~d}+$ IR group was dramatically reduced compared with that of the $\mathrm{Rub}_{2} \mathrm{~d}+\mathrm{IR}$ group (Fig. 4d), demonstrating that the high local concentration of ROS generated by $\mathrm{BiOBr}-\mathrm{H} / \mathrm{Rub}_{2} \mathrm{~d}$ under irradiation greatly improved the effectiveness of PDT therapeutic effects. In addition, no apparent body weight losses were found during the whole treatment (Fig. 4e). Imaging studies on the excised major organs and the tumor showed the strong fluorescence of the isolated tumor tissue after the i.v. injection of $\mathrm{BiOBr}-\mathrm{H} / \mathrm{Rub}_{2} \mathrm{~d}$ for $10 \mathrm{~min}$ and $24 \mathrm{~h}$, respectively (Fig. S31 and S32 $\dagger$ ). To further investigate the therapeutic effect of each treatment group, the tumor tissues were analysed by hematoxylin and eosin (H\&E) staining after the treatment. As shown in Fig. S33, $\uparrow$ the main organs including the heart, liver, spleen, lungs and kidneys showed no obvious damage after $\mathrm{BiOBr}-\mathrm{H} / \mathrm{Rub}_{2} \mathrm{~d}+$ IR treatment, while there was serious necrosis in the tumor tissues after the treatment. These results demonstrate the negligible toxicity of the $\mathrm{BiOBr}-\mathrm{H} / \mathrm{Rub}_{2} \mathrm{~d}$ PDT treatment and excellent therapeutic potential of $\mathrm{BiOBr}-\mathrm{H} / \mathrm{Rub}_{2} \mathrm{~d}$ for cancer therapy.

\section{Conclusions}

In summary, under the hypothesis that abundant OVs in $\mathrm{BiOBr}-$ $\mathrm{H}$ enable the improvement of the photocatalytic activity of a photosensitizer, we developed a novel theranostic agent by functionalizing the BiOBr-H with a PS $\left(\mathrm{Rub}_{2} \mathrm{~d}\right)$. The resultant $\mathrm{BiOBr}-\mathrm{H} / \mathrm{Rub}_{2} \mathrm{~d}$ indeed demonstrates outstanding therapeutic properties for PDT, which originated from the efficacy of OVs in the enhancement of ROS generation in tumor cells during light irradiation, conferring strong ablation effects both in vitro and in vivo. The phenomenon can be explained using density functional theory (DFT) calculations. All results suggest the feasibility of the concept (OVs can enhance ROS generation). Therefore, this work highlights the potential of vacancy engineering in the development of effective theranostic agents for cancer therapy. 


\section{Conflicts of interest}

There are no conflicts to declare.

\section{Acknowledgements}

Shanyue Guan, Li Wang and Si-Min Xu contributed to this work equally. The authors are grateful for the financial support from the National Natural Science Foundation of China (21805293 and 51473169), the Joint NSFC-ISF Research Program by National Natural Science Foundation of China and Israel Science Foundation (51561145004) and the Director Foundation of the Technical Institute of Physics and Chemistry, Chinese Academy of Sciences (Grant No. 2018-GSY). All animal procedures were performed in accordance with the Guidelines for Care and Use of Laboratory Animals of Technical Institute of Physics and Chemistry, Chinese Academy of Sciences, and the experiments were approved by the Animal Ethics Committee of Technical Institute of Physics and Chemistry, Chinese Academy of Sciences.

\section{Notes and references}

1 Z. Yu, Y. Ge, Q. Sun, W. Pan, X. Wan, N. Li and B. Tang, Chem. Sci., 2018, 9, 3563-3569.

2 W. Yin, T. Bao, X. Zhang, Q. Gao, J. Yu, X. Dong, L. Yan, Z. Gu and Y. Zhao, Nanoscale, 2018, 10, 1517-1531.

3 Z. Zhou, J. Song, R. Tian, Z. Yang, G. Yu, L. Lin, G. Zhang, W. Fan, F. Zhang, G. Niu, L. Nie and X. Chen, Angew. Chem., Int. Ed., 2017, 56, 6492-6496.

4 J. Ji, X. Li, T. Wu and F. Feng, Chem. Sci., 2018, 9, 5816-5821. 5 X. Li, S. Lee and J. Yoon, Chem. Soc. Rev., 2018, 47, 1174-1188. 6 W. Zhang, S. Li, X. Liu, C. Yang, N. Hu, L. Dou, B. Zhao, Q. Zhang, Y. Suo and J. Wang, Adv. Funct. Mater., 2018, 28, 1706375.

7 J. Ge, M. Lan, B. Zhou, W. Liu, L. Guo, H. Wang, Q. Jia, G. Niu, X. Huang, H. Zhou, X. Meng, P. Wang, C. S. Lee, W. Zhang and X. Han, Nat. Commun., 2014, 5, 4596.

8 W. S. Kuo, C. N. Chang, Y. T. Chang, M. H. Yang, Y. H. Chien, S. J. Chen and C. S. Yeh, Angew. Chem., Int. Ed., 2010, 49, 2711-2715.

9 Q. Chen, L. Feng, J. Liu, W. Zhu, Z. Dong, Y. Wu and Z. Liu, Adv. Mater., 2016, 28, 7129-7136.

10 M. Abbas, Q. Zou, S. Li and X. Yan, Adv. Mater., 2017, 29, 1605021.

11 D. He, L. Hai, X. He, X. Yang and H.-W. Li, Adv. Funct. Mater., 2017, 27, 1704089.

12 J. Kim, H. R. Cho, H. Jeon, D. Kim, C. Song, N. Lee, S. H. Choi and T. Hyeon, J. Am. Chem. Soc., 2017, 139, 10992-10995.

13 S. Cui, D. Yin, Y. Chen, Y. Di, H. Chen, Y. Ma, S. Achilefu and Y. Gu, ACS Nano, 2012, 7, 676-688.

14 F. E. Poynton, S. A. Bright, S. Blasco, D. C. Williams, J. M. Kelly and T. Gunnlaugsson, Chem. Soc. Rev., 2017, 46, 7706-7756.

15 C. Mari, V. Pierroz, R. Rubbiani, M. Patra, J. Hess, B. Spingler, L. Oehninger, J. Schur, I. Ott, L. Salassa, S. Ferrari and G. Gasser, Chem.-Eur. J., 2014, 20, 1442114436.
16 S. Guan, D. Yang, Y. Weng, H. Lu, X. Meng, X. Qu and S. Zhou, Adv. Healthcare Mater., 2018, 7, 1701123.

17 C. E. Rodríguez Torres, G. A. Pasquevich, P. M. Zélis, F. Golmar, S. P. Heluani, S. K. Nayak, W. A. Adeagbo, W. Hergert, M. Hoffmann, A. Ernst, P. Esquinazi and S. J. Stewart, Phys. Rev. B: Condens. Matter Mater. Phys., 2014, 89, 104411.

18 H. Li, J. Li, Z. Ai, F. Jia and L. Zhang, Angew. Chem., Int. Ed., 2018, 57, 122-138.

19 H. Wang, D. Yong, S. Chen, S. Jiang, X. Zhang, W. Shao, Q. Zhang, W. Yan, B. Pan and Y. Xie, J. Am. Chem. Soc., 2018, 140, 1760-1766.

20 H. Li, J. Shang, Z. Yang, W. Shen, Z. Ai and L. Zhang, Environ. Sci. Technol., 2017, 51, 5685-5694.

21 H. Li, F. Qin, Z. Yang, X. Cui, J. Wang and L. Zhang, J. Am. Chem. Soc., 2017, 139, 3513-3521.

22 P. Trogadas, J. Parrondo and V. Ramani, ACS Appl. Mater. Interfaces, 2012, 4, 5098-5102.

23 H. Chen, S. He, X. Cao, S. Zhang, M. Xu, M. Pu, D. Su, M. Wei, D. G. Evans and X. Duan, Chem. Mater., 2016, 28, 4751-4761.

24 Y. Zhao, X. Jia, G. Chen, L. Shang, G. I. N. Waterhouse, L.-Z. Wu, C.-H. Tung, D. O'Hare and T. Zhang, J. Am. Chem. Soc., 2016, 138, 6517-6524.

25 Y. Yang, L. C. Yin, Y. Gong, P. Niu, J. Q. Wang, L. Gu, X. Chen, G. Liu, L. Wang and H. M. Cheng, Adv. Mater., 2018, 30, 1704479.

26 H. Li, J. Shang, Z. Ai and L. Zhang, J. Am. Chem. Soc., 2015, 137, 6393-6399.

27 X. Shi, X. Chen, X. Chen, S. Zhou, S. Lou, Y. Wang and L. Yuan, Chem. Eng. J., 2013, 222, 120-127.

28 L. N. Lameijer, D. Ernst, S. L. Hopkins, M. S. Meijer, S. H. C. Askes, S. E. Le Devedec and S. Bonnet, Angew. Chem., Int. Ed., 2017, 56, 11549-11553.

29 Z. Zhang, B. Zhao and L. Hu, J. Solid State Chem., 1996, 121, 105-110.

30 N. Liu, R. A. Assink and C. J. Brinker, Chem. Commun., 2003, 370-371.

31 R. Tian, D. Yan, C. Li, S. Xu, R. Liang, L. Guo, M. Wei, D. G. Evans and X. Duan, Nanoscale, 2016, 8, 9815-9821.

32 S. Guan, Y. Weng, M. Li, R. Liang, C. Sun, X. Qu and S. Zhou, Nanoscale, 2017, 9, 10367-10374.

33 Y. Li, W. Zhang, J. Niu and Y. Chen, ACS Nano, 2012, 6, 51645173.

34 A. Agrawal, R. K. Saroj, T. A. Dar, P. Baraskar, P. Sen and S. Dhar, J. Appl. Phys., 2017, 122, 195303.

35 M. Ichimura, H. Sakakibara, K. Wada and M. Kato, J. Appl. Phys., 2013, 114, 114505.

36 S. K. Cushing, F. Meng, J. Zhang, B. Ding, C. K. Chen, C.-J. Chen, R.-S. Liu, A. D. Bristow, J. Bright, P. Zheng and N. Wu, ACS Catal., 2017, 7, 1742-1748.

37 A. Sarkar, K. Karmakar and G. G. Khan, J. Phys. Chem. C, 2017, 121, 25705-25717.

38 F. Zhao, Y. Zhao, Y. Liu, X. Chang, C. Chen and Y. Zhao, Small, 2011, 7, 1322-1337.

39 Z. Lv, H. Wei, Q. Li, X. Su, S. Liu, K. Y. Zhang, W. Lv, Q. Zhao, X. Li and W. Huang, Chem. Sci., 2018, 9, 502-512. 